MR. READE ON DRIFT-SEQUENCE, AND MR. MILNE ON COAST-ICE.

SIR,- - In answer to Mr. Mellard Reade's letter in your last, I ought to state that my object in calling attention to the Liverpool section was mainly to show that the Brick-clay of the N.W. of England is fully entitled to the epithet Boulder-clay; and that it is an original Boulder-clay, is proved by the number of limestone pebbles it contains which exhibit fine white scratches which would have been dimmed if not effaced by a process of re-transportation. The Liverpool drift-section does not show the three-fold division clearly, but even there we find gravel-beds full of erratic pebbles which must have been washed out of a pre-existing glacial clay (of which only hummocky patches remain), and their striæ effaced during an interglacial period when the transportation of striated stones had ceased.

You have lately published two very important articles on sea-ice, especially the article by Mr. Milne, which I think may be regarded as settling the question relative to the superiority of coast-ice as a transporting agent, and (with the exception of the more typical roches moutonnées) as a glaciating agent. That floating coast-ice did most of the work of transportation, and (so far as stones are concerned) glaciation, may be safely inferred from the glacial phenomena of the N.W. of England and Wales, as I have endeavoured to show in many articles in this Magazine, and in the Quart. Journ. Geol. Soc.

D. Mackintosh.

\title{
HUMAN REMAINS BENEATH BOULDER-CLAY?
}

Sir,-In the present Number of the Geological Magazine, p. 476, there is an instance recorded of flint implements, mammalian bones, etc., found in Brick-earth below the Boulder-clay in East Anglia.

I thought it might interest the readers of the Geonogical Magazine sufficiently, to justify me in recording the following which came under my notice the other day (16th inst.).

While some men were engaged in a brick pit by Toryd, Rhyl, they dug up, from a depth of 4 feet of slaty clay, a human skull with four teeth attached, a rib and piece of shoulder-bone; above the clay is a thickness of 3 feet of sand.

I am not competent enough to assign the right date to this clay, but believe it to be-older than the Boulder-clay which is very plentiful in this district. A little inland from the above, the Boulderclay lies in a great thickness above the slaty clay, with a band of peat and trunks of trees in some place intervening; but as we approach the sea, the Boulder-clay is wanting, and the following section is found :

$\begin{array}{lcccccccc}\text { Soil } \ldots & \ldots & \ldots & \ldots & \ldots & \ldots & \ldots & 1 \mathrm{ft} . & 3 \text { in. } \\ \text { Shingle with shells } & \ldots & \ldots & \ldots & \ldots & \ldots & 2 & 0 \\ \text { Sand with shells } & \ldots & \ldots & \ldots & \ldots & \ldots & 2 & 0 \\ \text { Slaty clay } & \ldots & \ldots & \ldots & \ldots & \ldots & \ldots & 2 & 0 \\ \text { Peat } \ldots & \ldots & \ldots & \ldots & \ldots & \ldots & \ldots & 3 & 0 \\ \text { Slaty clay, depth not known. } & & & & & & \end{array}$

RHYL, Oct. $17 t h, 1876$.

Sami. Parry. 